\title{
FAKTOR-FAKTOR YANG MEMENGARUHI KINERJA TENAGA KEPENDIDIKAN DI INSTITUT PERTANIAN BOGOR (IPB)
}

\author{
Yuhanna Aftika*), Jono M Munandar ${ }^{* *}$, dan Muhammad Syamsun $\left.{ }^{* * *}\right)$ \\ **) Departemen Manajemen, Fakultas Ekonomi Dan Manajemen, Institut Pertanian Bogor \\ Jl. Kamper, Wing 2 Level 5 Kampus IPB Darmaga, Bogor 16680
}

\begin{abstract}
The purpose of this study is to analyze factors that directly and indirectly affecting the employee performance of Bogor Agricultural University (IPB). There were 150 respondents involved in this research taken by with a sample pulling technique using the proportional random sampling. This research methodology used descriptive analysis and SEM analysis with PLS methods. The results showed that individual factors, psychological factors and organizational factors directly affect the performance of the administration staff. Individual psychological factors and organizational factors also influence indirectly to the performance of the administration staff through psychological factors. Organizational factor is the dominant factor affecting the performance of administration staff of IPB.
\end{abstract}

Keywords: individual factors, psychological factors, organizational factors, the performance of employees, partial least square (PLS)

\begin{abstract}
ABSTRAK
Penelitian ini bertujuan menganalisis faktor-faktor yang memengaruhi kinerja tenaga kependidikan di Institut Pertanian Bogor (IPB) baik secara langsung maupun tidak langsung serta menganalisis faktor dominan yang berpengaruh. Responden dalam penelitian ini sebanyak 150 orang dengan teknik penarikan sampel menggunakan proportional random sampling. Metode penelitian ini menggunakan analisis deskriptif dan analisis Structural Equation Modeling (SEM) dengan metode Partial Least Square (PLS). Variabel laten pada penelitian ini adalah faktor individu, faktor psikologi, faktor organisasi dan kinerja. Hasil penelitian menunjukkan bahwa faktor individu, faktor psikologi dan faktor organisasi berpengaruh secara langsung terhadap kinerja tenaga kependidikan di IPB. Faktor individu, psikologi, dan organisasi juga berpengaruh secara tidak langsung terhadap kinerja tenaga kependidikan melalui faktor psikologi. Faktor organisasi merupakan faktor dominan yang berpengaruh terhadap kinerja tenaga kependidikan di IPB.
\end{abstract}

Kata kunci : faktor individu, faktor psikologi, faktor organisasi, kinerja pegawai, partial least square (PLS)

${ }^{1}$ Alamat Korespondensi:

Email: yuhanna_aftika@yahoo.com

\section{PENDAHULUAN}

Persaingan yang semakin ketat terjadi pada berbagai jenis kegiatan usaha, termasuk persaingan antar perguruan tinggi. Persaingan yang kian kompetitif antara Perguruan Tinggi Negeri (PTN) maupun Perguruan Tinggi Swasta (PTS), menuntut setiap perguruan tinggi untuk meningkatkan keunggulan yang dimilikinya. Dapat bersaing atau tidaknya suatu perguruan tinggi tergantung pada sumber daya yang dimiliki perguruan tinggi tersebut. Di antara sumber daya yang dimiliki, sumber daya manusia merupakan harta kekayaan yang terpenting dan mempunyai kontribusi paling besar bagi keberhasilan suatu perguruan tinggi. Beberapa perguruan tinggi negeri dan swasta Indonesia masuk kelompok 5.000 perguruan tinggi terbaik dunia berdasarkan pemeringkatan yang dilakukan Webometrics dan Keputusan Menteri Riset, Teknologi, dan Pendidikan Tinggi (Kemenristek) Republik Indonesia. Hal tersebut dapat dilihat pada Gambar 1 dan Gambar 2. 
Berdasarkan pemeringkatan perguruan tinggi tersebut, untuk menghadapi tantangan persaingan yang semakin ketat antar perguruan tinggi, tentunya membuat Institut Pertanian Bogor (IPB) sebagai salah satu perguruan tinggi terkemuka di Indonesia untuk lebih meningkatkan keunggulan yang dimilikinya. Salah satu aspek terpenting dalam menciptakan suatu keunggulan bersaing adalah dengan meningkatkan kualitas sumber daya manusia yang dimiliki. Pegawai sebagai sumber daya manusia yang dimiliki institusi adalah manusia yang mempunyai sifat kemanusiaan, perasaan dan kebutuhan yang beraneka ragam. Kebutuhan ini bersifat fisik maupun nonfisik, kebutuhan tersebut harus dipenuhi agar dapat hidup secara layak dan manusiawi. Hal ini menyebabkan timbulnya suatu pendekatan yang berdasarkan pada kesejahteraan pegawai dalam manajemen sumber daya manusia. Salah satu masalah pokok dalam manajemen sumber daya manusia adalah bagaimana mencari cara yang terbaik untuk mencapai kinerja pegawai yang optimal. IPB memiliki pegawai yang cukup banyak dan struktur organisasional yang cukup kompleks.
Hal ini terlihat dari adanya sembilan Fakultas serta pegawai yang menunjang di dalamnya, diantaranya adalah pegawai tenaga pendidik dan tenaga kependidikan. Tenaga kependidikan merupakan salah satu bagian penting IPB. Tenaga kependidikan merupakan mitra kerja yang berpengaruh sangat besar demi kelancaran, kemajuan dan kesuksesan institusi. Jumlah tenaga kependidikan pada sembilan fakultas IPB yaitu 1.212 pegawai yang terdiri dari 1023 Pegawai berjenis kelamin laki-laki dan 189 Pegawai berjenis kelamin perempuan (data internal IPB, Januari 2016). Berbagai kompleksitas kegiatan dan peran tenaga kependidikan yang berbeda menuntut mereka harus tetap fokus dalam menjalankan kegiatannya. Oleh karena itu, sumber daya manusia tersebut harus dikelola dengan optimal sehingga dapat memuaskan kedua belah pihak.

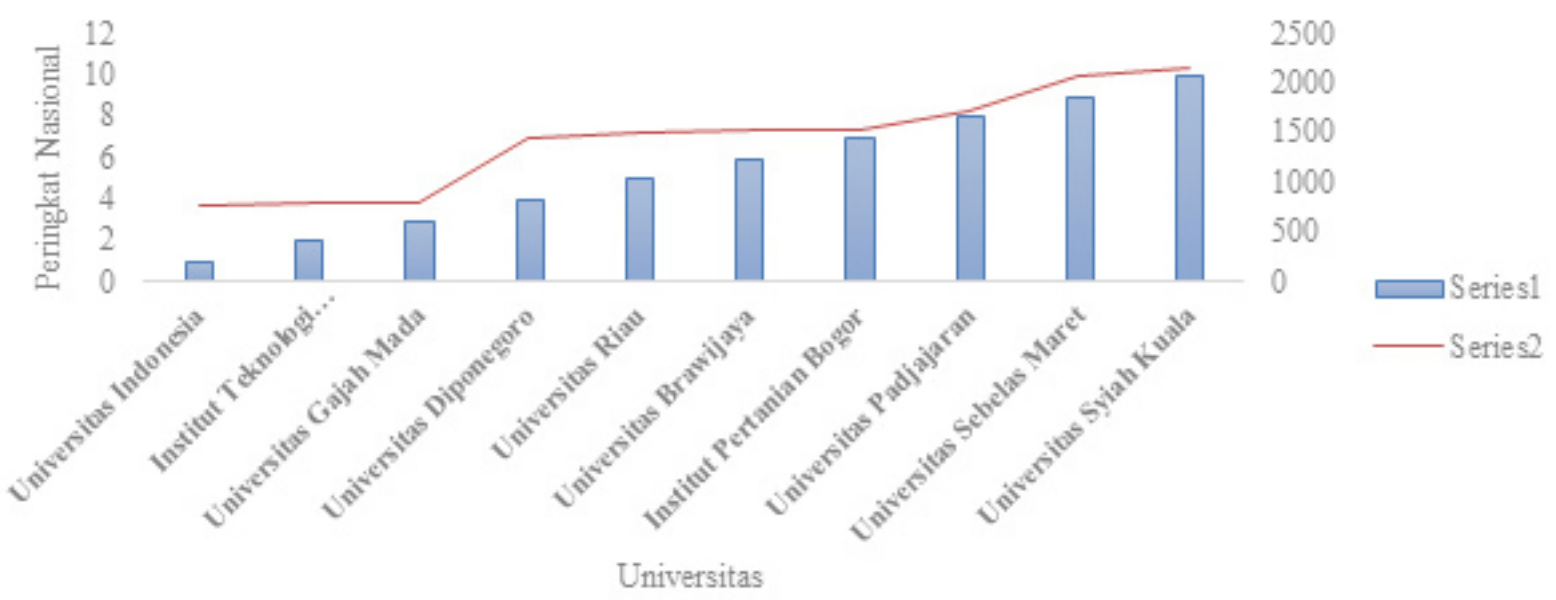

Gambar 1.Pemeringkatan berdasarkan webometrics (www.webometrics.info, 2016)

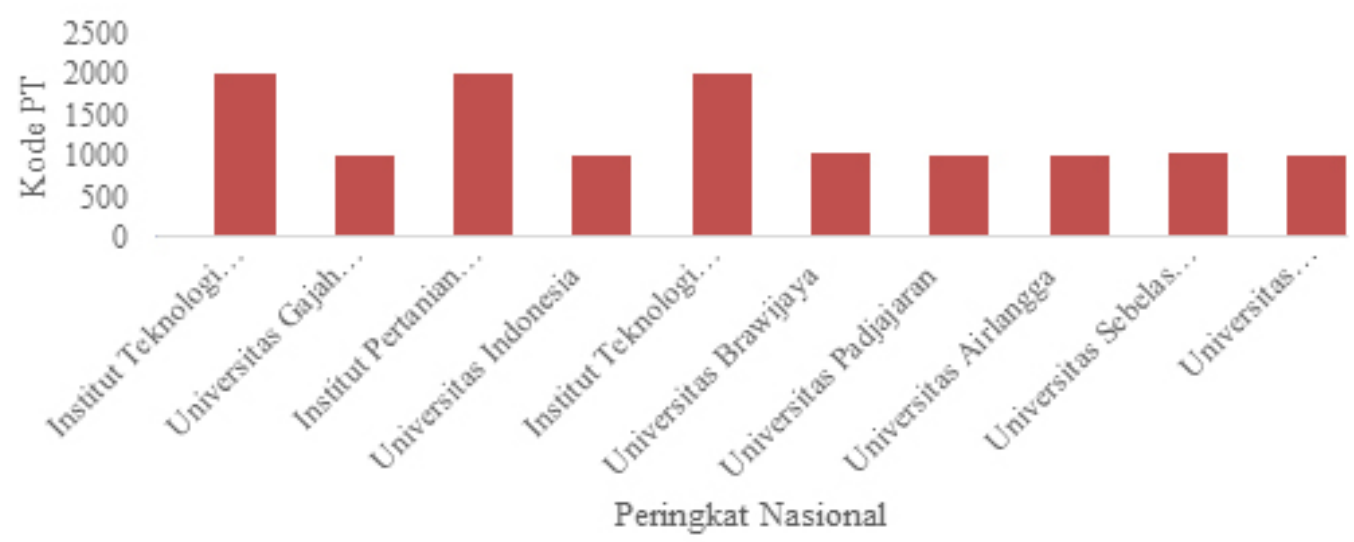

Gambar 2. Pemeringkatan Perguruan Tinggi berdasarkan Kemenristek (www.ristek.go.id, 2015) 
Saat ini, terlihat bahwa kinerja yang dilakukan oleh pihak direktorat Sumber Daya Manusia IPB dinilai berdasarkan faktor kehadiran, produktivitas dan kualitas kerja. Akan tetapi penilaian kinerja tersebut dinilai hanya untuk tenaga pendidik yang berstatus pegawai negeri sipil (PNS) saja. Ketidaksiapan institusi dalam memelihara dan mengelola sumber daya manusianya dapat menimbulkan permasalahan yang merugikan dan menghancurkan tujuan institusi tersebut jika hanya memperhatikan dari sisi kinerja pegawai tenaga pendidik saja, namun untuk tenaga kependidikan kurang diperhatikan. Oleh karena itu, IPB perlu melakukan tindakan-tindakan yang dapat meningkatkan kinerja tenaga kependidikannya melalui faktor-faktor yang memengaruhi kinerjadan memberikan perhatian yang lebih baik terhadap masalah kerja mereka agar kinerja meningkat dan tujuan institusi dapat tercapai.

Beberapa penelitian yang terkait dengan penelitian ini telah dilakukan oleh Juhdi et al. (2010) dengan judul Factors Influencing Internaland ExternalEmployability of Employees berhasil membuktikan bahwa praktek manajemen karir formal positif terkait dengan kerja eksternal dan kerja internal. Praktek manajemen karir informal hanya ditemukan secara signifikan terkait dengan kerja eksternal. Sedangkan hubungan dengan kerja internal tidak signifikan. Pelatihan yang diterima oleh karyawan adalah baik terkait dengan kerja internal dan eksternal. Di sisi lain, pengalaman kerja yang hanya secara signifikan terkait dengan kerja internal. Pendidikan dan penguasaan ditemukan hanya memberikan pengaruh yang signifikan terhadap kerja eksternal.

Boriban (2014) dengan tujuan penelitiannya untuk mempelajari faktor motivasi dan jugauntuk mempelajari faktor kaitannya dengan prestasi kerja (kinerja) yang membandingkan faktor motivasi dibawah klasifikasi faktor pribadi seperti jenis kelamin, usia, pendapatan, tingkat pendidikan, status perkawinan, dan Durasi kerja. Hasil temuan menunjukkan bahwa aspek promosi pekerjaan dan gaji di tingkat moderat. Selain itu, temuan juga menunjukkan bahwa motivasi yang memengaruhi kinerja, kebijakan dan manajemen,promosi kerja, dan hubungan interpersonal. Sebaliknya, Osibiya (2014) dalam jurnalnya mengungkapkan faktorfaktor yang memengaruhi motivasi pekerja dan pengaruh faktor motivasi yang diidentifikasi pada kinerja pekerja dan secara keseluruhan produktivitas. Survei mengungkapkan bahwa di antara sepuluh faktor kritis (teamwork, bekerja berdasarkan kontrak, pengawasan berdasarkan kepemimpinan dengan contoh dan penyediaan peralatan) memiliki efek yang besar pada motivasi serta berdampak pada produktivitas. Oleh karean itu, komunikasi, cinta, dan rasa memiliki berkesempatan untuk melakukan tugas yang menantang.

Penelitian yang dilakukan Thao (2010) mengenai faktor-faktor yang memengaruhi kinerja karyawan mengatakan bahwa sebagian besar organisasi sepenuhnya menyadari pentingnya kinerja karyawan, meningkatkan kinerja karyawan atau untuk mengetahui cara-cara di mana tingkat tinggi kinerja karyawan dapat dicapai, yaitu menjadi salah satu factor yang menentukan keberhasilan organisasi. Kinerja tenaga kerja dapat ditingkatkan dengan menempatkan faktor yang meningkatkan karyawan seperti tingkat motivasi, kreativitas, kepuasan kerja, dan kenyamanan lingkungan kerja. Penelitian ini juga bertujuan untuk mengidentifikasi factor yang meliputi kepemimpinan, budaya organisasi, lingkungan kerja, motivasi dan pelatihan. Sedangkan penelitian yang dilakukan Munawaroh et al. (2013), membahas tentang factor yang memengaruhi kinerja individu dalam kantor pemerintah Indonesia. Reformasi di kantor-kantor pemerintah Indonesia menyebabkan banyak perubahan substansial, dan tuntutan ditingkatkan pertunjukan pekerjaan sementara faktanya dibilang memuat karyawan dengan lebih banyak pekerjaan. Hasil ini penting karena mereka menyoroti pentingnya kebutuhan untuk berprestasi untuk keberhasilan reformasi di kantor ini, dan dengan ekstensi reformasi di Indonesia.

Dari beberapa hasil penelitian terdahulu, perbedaan dengan penulis teliti yaitu melihat segi faktor-faktor yang memengaruhi kinerja yang tidak hanya dari segi faktor motivasi dan lingkungan kerja saja, namun secara keseluruhan yang tertuang dalam teori Gibson (2000) yaitu faktor individu, faktor organisasi, dan faktor psikologi. Gibson (2000) menyampaikan model teori kinerja dan melakukan analisis terhadap sejumlah variabel yang memengaruhi perilaku dan kinerja individu. Variabel yang memengaruhi kinerja adalah individu, perilaku, psikologi dan organisasi, meliputi (1) variabel individu dikelompokan pada sub variabel kemampuan dan ketrampilan, latar belakang dan demografis. Variabel kemampuan dan keterampilan merupakan faktor utama yang memengaruhi perilaku kerja dan kinerja individu. Variabel demografis mempunyai pengaruh yang tidak langsung, (2) variabel psikologi terdiri dari subvariabel persepsi, 
sikap, kepribadian, belajar dan motivasi. Variabel ini dipengaruhi oleh keluarga, tingkat sosial pengalaman kerja sebelumnya dan variabel demografis, (3) variabel organisasi, mempunyai efek tidak langsung terhadap perilaku dan kinerja individu. Variabel organisasi digolongkan dalam sub variabel sumber daya, kepemimpinan, imbalan, struktur dan desain pekerjaan. Sub Variabel imbalan akan berpengaruh untuk meningkatkan motivasi kerja yang pada akhirnya secara langsung akan meningkatkan kinerja individu. Akan tetapi dalam penelitian ini, terdapat variabel tambahan yang mendukung faktor-faktor yang memengaruhi kinerja diantaranya yaitu variabel budaya organisasi, dan engagement. Menurut Hewwit (2011), employee engagement merupakan keadaan seorang pegawai secara pribadi bertanggung jawab dan berkomitmen untuk menyelesaikan pekerjaannya dengan sangat baik. Adanya sebuah organisasi/perusahaan yang memiliki budaya yang kuat juga akan mengakibatkan semua anggotanya menganut nilai-nilai yang sama dan menjalankan kegiatan yang relatif bersifat konsisten, sehingga budaya organisasi yang kuat sangat berkaitan dengan kinerja yang unggul.

Setiap tenaga kependidikan memiliki kemampuan dan keterampilan yang berbeda antara satu dengan yang lain, oleh karena itu IPB harus mengetahui apa yang menimbulkan dorongan (drive) dan kebutuhan (need) tenaga kependidikan dalam bekerja. IPB membutuhkan tenaga kependidikan yang mampu, cakap, terampil dan memiliki keinginan untuk bekerja dengan giat dalam upaya mencapai hasil kerja yang optimal, akan tetapi kemampuan, kecakapan dan keterampilan tidak akan berarti jika tenaga kependidikan tersebut tidak memiliki semangat kerja, motivasi, kedisiplinan dan kinerja yang tinggi. Sehingga kondisi ini dapat menjadi penyakit yang mengancam produktivitas kerja yang mengikis profit institusi. Oleh karena itu, IPB perlu melakukan tindakan-tindakan yang dapat meningkatkan kinerja kerja tenaga kependidikannya dengan memberikan perhatian yang lebih baik terhadap masalah kepuasan kerja mereka agar kinerja meningkat dan tujuan institusi dapat tercapai. IPB juga perlu berusaha mendayagunakan keterampilan tenaga kependidikan yang dimiliki sehingga mendorong mereka untuk meningkatkan pengetahuan dan keterampilan, karena tenaga kependidikan merupakan sumber daya yang harus dikembangkan bukan sekedar digunakan. Sehingga IPB dapat terus meningkatkan kualitas sumber daya yang ada di dalamnya dan menghasilkan lulusan yang berkompeten. Lulusan tersebut diharapkan dapat memajukan dan menyumbangkan ilmu pengetahuan di Indonesia.

Kinerja yang baik akan memberikan pengaruh bagi keberhasilan organisasi. Untuk mengetahui faktorfaktor yang dominan memengaruhi kinerja dan bagaimana hubungan antara faktor-faktor tersebut dengan kinerja tenaga kependidikan di IPB maka perlu dilakukan penelitian yang bertujuan untuk menganalisis faktor-faktor yang terkait faktor indvidu, psikologi, dan organisasi yang memengaruhi kinerja tenaga kependidikan di seluruh fakultas IPB, menganalisis sejauhmana faktor-faktor tersebut berpengaruh secara langsung dan tidak langsung terhadap kinerja tenaga kependidikan di seluruh fakultas IPB, dan menganalisis faktor dominan yang memengaruhi kinerja tenaga kependidikan di seluruh fakultas IPB.

\section{METODE PENELITIAN}

Jenis data yang digunakan dalam penelitian ini adalah data primer yaitu data yang bersumber dari hasil penelitian lapangan berupa penyebaran kuesioner yang berisi sejumlah pertanyaan tertulis yang akan digunakan untuk memperoleh informasi dari responden di sembilan fakultas IPB. Selain data primer, peneliti juga menggunakan data sekunder, yaitu data yang berasal dari sumber lainnya. Data sekunder dapat diperoleh dari data kepegawaian pada tahun 2015 di lingkup Direktorat SDM IPB khususnya pada bagian tenaga kependidikan terutama mengenai kinerja pegawai, serta literatur yang berkaitan dengan penelitian seperti buku, jurnal, dan pustaka lainnya yang bersumber dari internet.

Responden dalam penelitian ini adalah tenaga kependidikan yang bekerja di sembilan Fakultas IPB yang berlokasi di kampus IPB Darmaga, Bogor. Penelitian ini tidak untuk menilai kinerja pegawai, namun ruang lingkup terbatas pada analisis terhadap faktor-faktor yang berasal dari faktor individu, faktor psikologis, dan faktor organisasi yang memengaruhi kinerja tenaga kependidikan di sembilan fakultas IPB. Hubungan antar pribadi, pengakuan dan pekerjaan itu sendiri. Penelitian ini menggunakan data primer yang diperoleh dari data hasil kuesioner dan wawancara tenaga kependidikan serta informasi yang berkaitan dengan sumber daya manusia. 
Tabel 1. Jumlah sampel berdasarkan karakteristik unit/bagian

\begin{tabular}{lcccc}
\hline \multicolumn{1}{c}{ Populasi } & \multicolumn{2}{c}{ Jumlah Populasi (orang) } & \multicolumn{2}{c}{ Jumlah Sampel (orang) } \\
\cline { 2 - 5 } \multicolumn{1}{c}{ Per unit kerja } & PNS & Honorer & 11 & Honorer \\
\hline FAPERTA & 89 & 105 & 10 & 6 \\
FKH & 77 & 46 & 10 & 11 \\
FPIK & 80 & 91 & 10 & 2 \\
FAPET & 85 & 5 & 8 & 5 \\
FAHUTAN & 67 & 44 & 11 & 7 \\
FATETA & 92 & 60 & 13 & 9 \\
FMIPA & 105 & 74 & 6 & 6 \\
FEM & 46 & 51 & 4 & 8 \\
FEMA & 31 & 64 & 83 & 67 \\
\multicolumn{1}{c}{ Jumlah } & 672 & 540 & 150 & \\
\hline
\end{tabular}

Sumber: Data Internal IPB, Maret 2016

Teknik penarikan sampel yang digunakan dalam penelitian ini adalah menggunakan proportional random sampling karena sampel yang telah terpilih dapat mewakili semua populasi dan besar peluang setiap anggota populasi untuk menjadi sampel sama besar, sehingga menjamin dasar sampel yang terpilih bisa mewakili semua populasinya. Agar dapat menguji dugaan tersebut maka sampel nya harus mewakili keterwakilan diseluruh elemen jenjang manajemen yang ada. Adapun jumlah tenaga kependidikan yang dijadikan responden adalah sebanyak 150 orang yang sesuai dengan pendapat Ghozali (2008), bahwa ukuran sampel 100 sampai 150 merupakan ukuran sampel ketika menggunakan SEM sebagai alat analisis. Rumus sebaran $\left(\sum\right)$ responden pada setiap bagian secara proporsional adalah $\sum$ Pegawai tiap bagian dibagi Pegawai total keseluruhan fakultas dikali 150 .

Analisis data yang dilakukan dalam penelitian ini adalah menggunakan metode Struktural Equation Modeling (SEM) dengan pendekatan Partial Least Square (PLS) dimana perhitungan statistik nya dilakukan dengan software SmartPLS versi 3.0. Analisis data dengan PLS tidak mengasumsikan adanya distribusi tertentu untuk estimasi parameter sehingga teknik parametrik untuk menguji signifikansi parameter tidak diperlukan (Chin, 1998 dalam Ghazali, 2008). Variabel dalam penelitian ini terdiri dari empat variabel, yaitu faktor individu (X1), faktor psikologi (X2), faktor organisasi (X3) dan kinerja tenaga kependidikan (Y). Setiap variabel laten memiliki masing-masing variabel manifest (indikator) sesuai yang telah dijabarkan sebelumnya pada operasionalisasi variabel.
Kerangka pemikiran penelitian ini diawali dengan uji faktor-faktor yang memengaruhi kinerja. Informasi yang didapatkan untuk melakukan uji faktor yang memengaruhi kinerja didapatkan dari wawancara dan kuesioner. Faktor-faktor yang memengaruhi kinerja dalam penelitian ini menggunakan gabungan dari teori Gibson (2000), yaitu faktor individu, faktor psikologi, dan faktor organisasi. Dalam penelitian ini, faktor kinerja tenaga kependidikan didapat dari lembaran penilaian kinerja pada IPB. Faktor-faktor yang dinilai dalam variabel kinerja yaitu produktivitas dan kualitas kerja: inisiatif/kreativitas, tanggung jawab, Kerja sama dan kedisiplinan. Di dalam mencari pengaruh faktor-faktor yang memengaruhi kinerja tenaga kependidikan, penelitian ini menggunakan alat analisis SEM dengan variabel laten eksogen yaitu faktor individu, faktor psikologi, dan faktor organisasi dan variabel laten endogen yaitu kinerja. Dari faktor-faktor yang memengaruhi kinerja tenaga kependidikan akan mengarahkan manajemen dalam melakukan implikasi manajerial untuk melakukan tindakan-tindakan yang dapat mencapai kinerja yang optimal tenaga kependidikannya. Dengan adanya upaya tersebut maka diharapkan kinerja tenaga kependidikan meningkat. Alur pemikiran dari penelitian ini dapat dilihat pada Gambar 3.

Hipotesis yang diajukan untuk penelitian ini yaitu sebagai berikut:

1. Hipotesis Model 1: Model Pengaruh Langsung (Direct effect)

$\mathrm{H} 1=$ Faktor individu berpengaruh secara signifikan terhadap kinerja pegawai

$\mathrm{H} 2=$ Faktor psikologis berpengaruh secara signifikan terhadap kinerja pegawai 
$\mathrm{H} 3=$ Faktor organisasi berpengaruh secara signifikan terhadap kinerja pegawai

2. Hipotesis Model 2: Model Pengaruh Tidak Langsung (Indirect effect)

H4 = Faktor individu berpengaruh secara signifikan terhadap faktor psikologi

H5 = Faktor organisasi berpengaruh secara signifikan terhadap faktor psikologi

H6= Faktor individu berpengaruh secara signifikan terhadap faktor organisasi.

\section{HASIL}

Jumlah pegawai tenaga kependidikan di sembilan fakultas pada Institut Pertanian Bogor (IPB) sebanyak 150 orang yang terdiri dari laki-laki dan perempuan. karakteristik tenaga kependidikan berdasarkan kategori jenis kelamin menunjukkan bahwa tenaga kependidikan berjenis kelamin laki-laki lebih banyak dari pada tenaga kependidikan berjenis kelamin wanita. Perbedaan jumlah persentase antara pegawai tenaga kependidikan yang berjenis kelamin laki-laki yaitu sebanyak 80 orang atau sebesar $53 \%$ dan perempuan sebanyak 70 orang atau sebesar $47 \%$ pada dasarnya perbedaan antara keduanya tidak terlalu signifikan sehingga memberikan gambaran kepada kita bahwa IPB tidak membeda-bedakan gender dalam merekrut dan mempekerjakan tenaga kependidikan. Selain itu, jenis pekerjaan yang lebih cenderung ke hal-hal administrasi dan membutuhkan kerapihan serta ketekunan, yang biasanya dilakukan oleh wanita, tidak menjadikan IPB langsung memilih tenaga kependidikan wanita untuk mengisi pos-pos pekerjaan tersebut. Semuanya dikembalikan pada kompetensi dan minat masingmasing tenaga kependidikan. Usia pegawai tenaga kependidikan di sembilan fakultas pada IPB berkisar antara usia 20-50 tahun yang memiliki taraf pendidikan SMA, yaitu sebanyak 81 orang atau $54 \%$. Hal ini berarti bahwa tenaga kependidikan lebih banyak dibutuhkan dalam pegawai yang berstatus honorer. Walaupun pada kenyataannya terdapat tenaga kependidikan dengan tingkat pendidikan S1 sebanyak 37 orang atau sebesar $25 \%$, Diploma sebanyakr 18 orang atau sebesar $12 \%$, dan S2 sebanyak 5 orang atau sebesar $6 \%$. Hal ini terjadi karena para responden merupakan tenaga kependidikan yang memiliki masa kerja yang cukup lama (lebih dari 10 tahun) yang memulai karirnya dari jabatan paling rendah, sehingga posisi mereka saat ini lebih dipengaruhi oleh jasa dan prestasi mereka terhadap organisasi. masa kerja, mayoritas tenaga kependidikan yang menjadi responden memiliki masa kerja 5-15 tahun yaitu sebesar 32\%. Berbanding lurus dengan usia, responden didominasi oleh tenaga kependidikan dengan masa kerja 5-15 tahun dengan jumlah hampir dari setengah responden, yaitu sebanyak 48 orang. Berdasarkan status pegawai, tenaga kependidikan yang berstatus PNS berjumlah 83 orang, yaitu sekitar 55\% dan yang berstatus non-PNS berjumlah 67 orang yaitu sekitar 45\%, dengan tingkat golongan III sebesar $67 \%$.

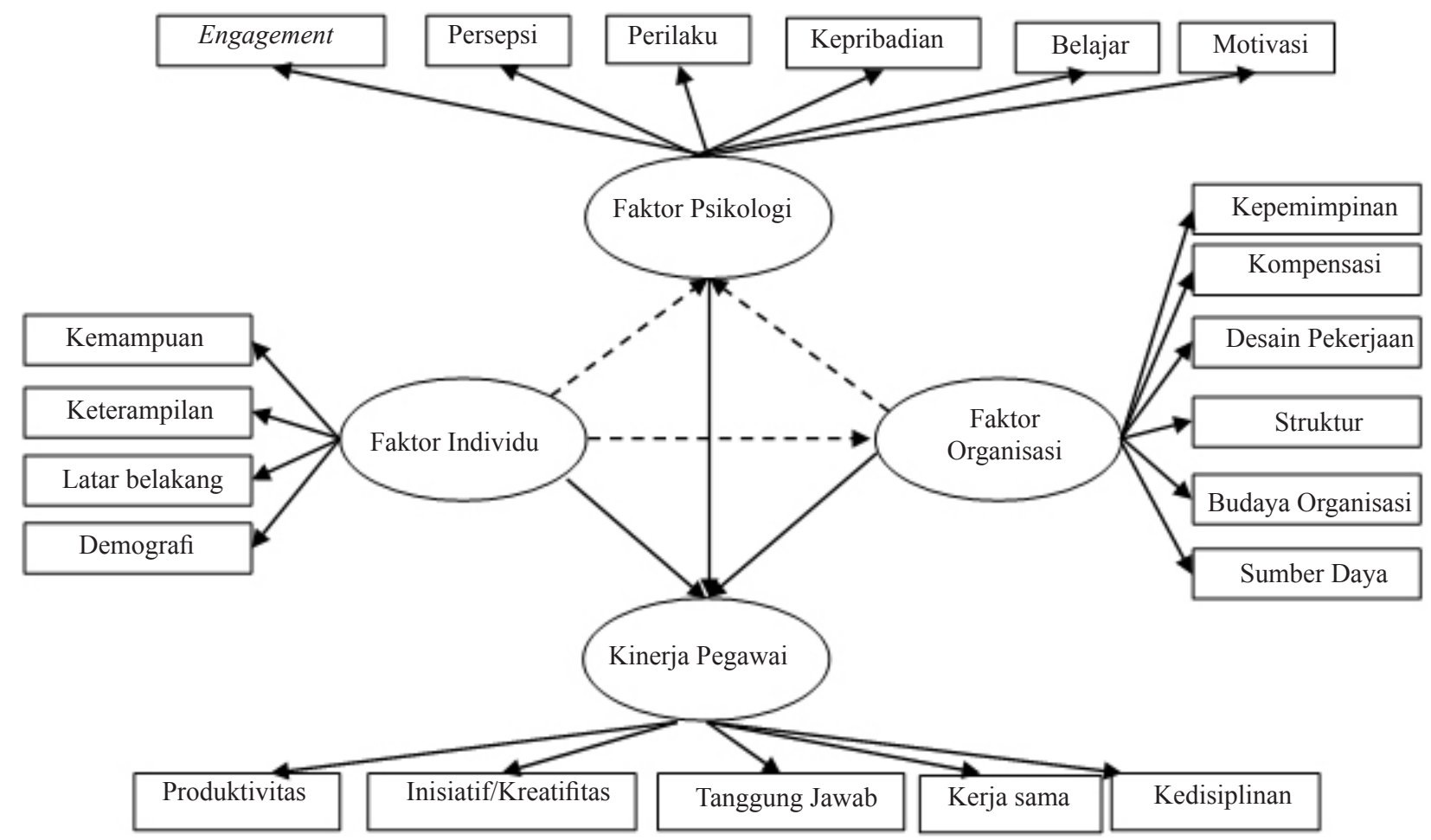

Gambar 3. Alur pemikiran dari penelitian 


\section{Pengaruh Faktor Individu, Psikologi, dan Organisasi terhadap Kinerja Tenaga Kependidikan}

Penelitian ini terdiri dari empat variabel laten (tak terukur langsung), yaitu faktor individu (X1), faktor psikologi (X2), faktor organisasi (X3) dan kinerja PNS (Y). Setiap variabel laten memiliki indikator-indikator (variable manifest) sesuai dengan yang dijabarkan dalam operasionalisasi variabel. Evaluasi model PLS dilakukan dengan mengevaluasi outer model (model pengukuran) dan inner model (model struktural) yang dapat dilakukan sekaligus (Ghozali, 2008).

Evaluasi outer model merupakan model pengukuran untuk menilai validitas dan reliabilitas model melalui iterasi algoritma, melalui parameter convergent validity (validitas konvergen), discriminant validity (validitas diskriminan), composite reliability dan cronbach's alpha. Validitas konvergen dicerminkan dari nilai loading factor yang merefleksikan kekuatan interelasi antara konstruk dengan indikator-indikatornya. Menurut Chin dalam Ghozali (2008) untuk penelitian tahap awal dari pengembangan skala pengukuran nilai loading 0,5 sampai 0,6 sudah dianggap cukup. Dalam penelitian ini disyaratkan semua indikator memiliki nilai loading factor diatas 0,6 sehingga indikator yang memiliki loading factor kurang dari 0,6 akan dieliminasi. Sebaliknya, evaluasi model struktural (inner model) untuk menggambarkan hubungan antar variabel laten berdasarkan pada substantive theory. Perancangan model struktural ini hubungan antar variabel laten didasarkan pada rumusan masalah atau hipotesis penelitian. Evaluasi model dalam penelitian ini dilakukan untuk melihat pengaruh faktor individu, psikologi, dan organisasi terhadap kinerja tenaga kependidikan di IPB. Secara umum, evaluasi dan intepretasi model dapat dilihat sebagai berikut:

\section{Model Pengukuran (Outer Model)}

Model Pengukuran atau outer model mendefinisikan bagaimana setiap blok indikator berhubungan dengan variabel latennya. Evaluasi outer model dilakukan terhadap konstruk yang direfleksikan oleh indikatorindikatornya. Ukuran refleksif indikator dengan konstruknya dikatakan tinggi jika berkorelasi atau memiliki nilai loading factor lebih dari 0,7 dengan konstruk yang ingin diukur. Untuk penelitian tahap awal dari pengembangan, skala pengukuran dengan nilai loading faktor 0,5 sampai 0,6 dianggap cukup (Ghazali, 2008). Model akhir pengaruh langsung (direct effect) dan tidak langsung (indirect effect) dapat dilihat pada Gambar 4. Hasil analisis menunjukkan nilai loading factor, nilai composite reability masing masing konstruk dan nilai AVE masing-masing konstruk melebihi standar yang ditetapkan baik pada model pengaruh langsung/direct effect maupun pada model pengaruh tidak langsung/indirect effect.

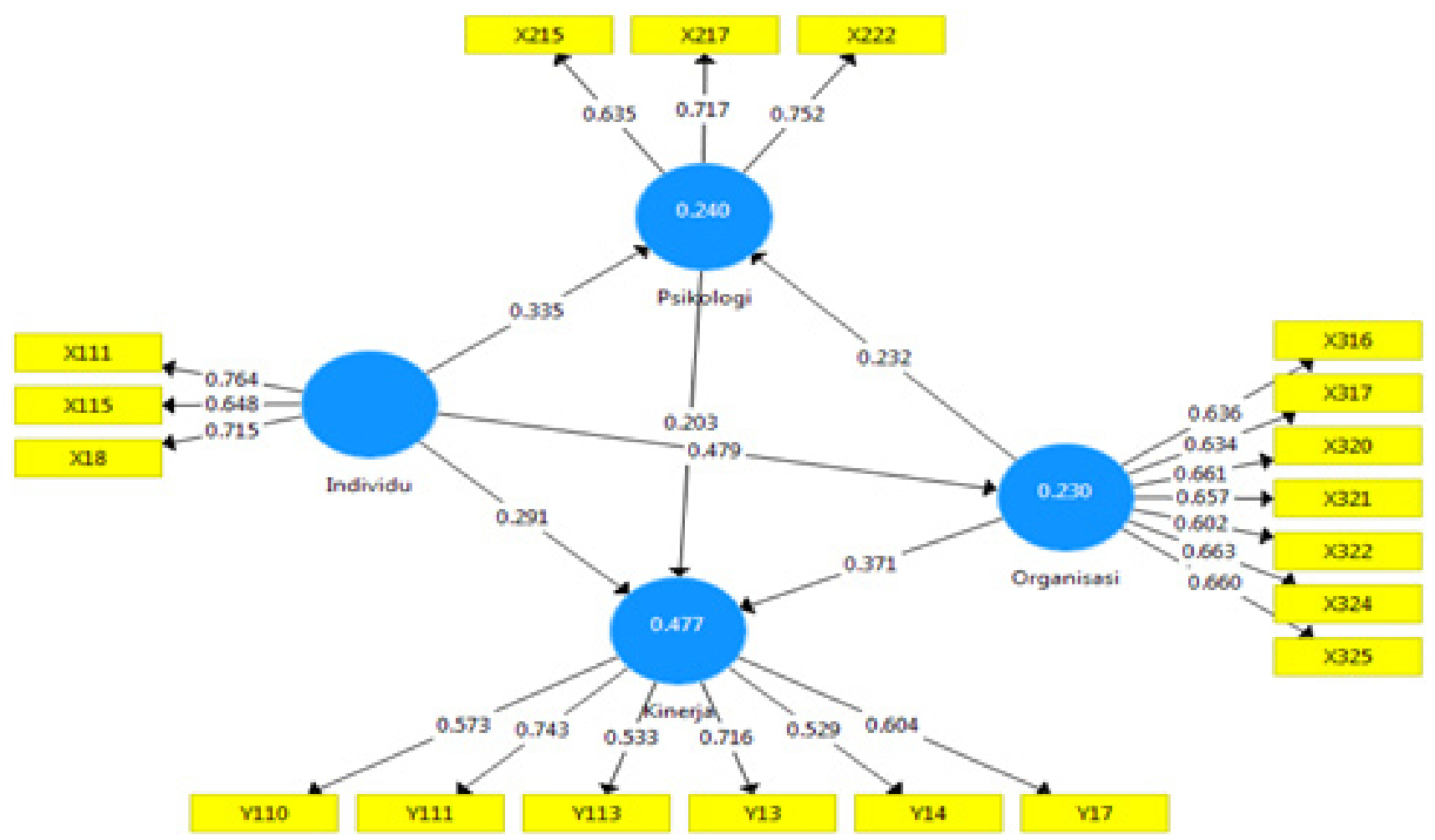

Gambar 4. Model akhir pengaruh langsung (direct effect) dan tidak langsung (indirect effect) 
Diketahui bahwa indikator yang dicerminkan oleh setiap variabel pada model pengaruh langsung berbeda dengan model pengaruh tidak langsung. Dari model dapat diketahuibahwapada faktorindividu, X1.11 (Latar belakang keluarga mendukung karir dan pekerjaan di organisasi), merefleksikan interelasi terbesar dalam menggambarkan faktor individu dengan masingmasing nilai loading factor 0,772 dan 0,764 . Seberapa baik human society dengan implikasinya pada bisnis dan perekonomian, tergantung pada keluarga, sehingga dalam hal ini latar belakang keluarga mendukung karir dan pekerjaan di organisasi merupakan hal yang paling dominan dalam mencerminkan faktor individu, yang nantinya akan berpengaruh pada kinerja pegawai di organisasi tersebut. Beberapa penelitian yang terkait dengan penelitian ini mendukung hasil penelitian, seperti yang dilakukan oleh Irawan et al. (2015), Hameed (2009), dan Marpaung (2013) bahwa faktor individu merupakan hasil penelitian dengan nilai koefisien terbesar yang dicerminkan oleh kemampuan, keterampilan, dan latar belakang yang menjadi perhatian utama organisasi untuk ditingkatkan secara simultan yang dapat meningkatkan kinerja pegawai.

Dari indikator yang dicerminkan oleh variabel laten faktor psikologi yaitu indikator X2.22 (pencapaian kinerja organisasi menumbuhkan rasa bangga tersendiri pada pegawai) mencerminkan interelasi terbesar baik pada model, dengan masing-masing loading factor sebesar 0,740 dan 0, 752. Perusahaan sebagai organisasi memiliki ketergantungan yang saling terkait dengan individu dalam perusahaan itu sendiri. Pegawai sebagai individu dalam perusahaan merupakan bagian dari struktur organisasi yang memiliki peranan besar dalam menentukan tercapainya tujuan perusahaan. Dalam hasil penelitian Ton (2013), dan Khan (1990) bahwa kinerja pegawai merupakan dasar bagi pencapaian kinerja dan prestasi perusahaan, sehingga pengelolaan pegawai sebagai sumber daya yang potensial merupakan tugas utama manajemen. Pengelolaan sumber daya manusia menjadi sangat penting karena perusahaan dapat mencapai kinerja yang diharapkan serta memiliki keunggulan kompetitif ketika orang didalamnya melakukan apa yang terbaik dari mereka, apa yang mereka senangi serta kuatnya faktor kepemilikan secara psikologis dalam melaksanakan dan memberi hasil pada pekerjaan mereka, kesemua hal tersebut menjadi faktor motivasi karyawan dalam menumbuhkan rasa bangga terhadap pencapaian sesuatu yang telah dikerjakan pada tujuan organisasi. Dalam hasil penelitian Osibiya (2014) dan Boriban (2014) mengatakan bahwa faktor motivasi diklasifikasikan menjadi faktor pribadi seperti jenis kelamin, usia, pendapatan, tingkat pendidikan, dan status perkawinan. Temuan nya menunjukkan bahwa aspek promosi pekerjaan dan gaji ditingkat moderat memengaruhi kinerja pekerjaan cabang. Peningkatan kinerja pegawai sangat dipengaruhi oleh faktor psikologis yang disebut dengan employee engagement.

Hasil penelitian pada model tersebut, indikator yang merefleksikaninterelasi terbesar dalam menggambarkan faktor organisasi adalah indikator X3.24 (setiap pekerjaan di unit kerja dilakukan secara teamwork) dengan loading factor sebesar 0,673 dan 0,663. Pada dasarnya setiap individu yang tergabung didalam sebuah organisasi memiliki budaya yang berbeda, disebabkan mereka memiliki latar belakang budaya yang berbeda, namun semua perbedaan itu dilebur menjadi satu di dalam sebuah budaya, yaitu budaya organisasi, untuk menjadi sebuah kelompok yang bekerja sama dalam mencapai tujuan organisasi sebagaimana yang telah disepakati bersama sebelumnya. Tetapi dalam proses tersebut tidak tertutup kemungkinan ada individu yang bisa menerima dan juga yang tidak bisa menerimanya, yang mungkin bertentangan dengan budaya yang dimilikinya. Hal ini pada pegawai tenaga kependidikan di Institut Pertanian Bogor (IPB) merasa bahwa setiap pekerjaan di unit kerja dilakukan secara teamwork sehingga tujuan organisasi dapat tercapai dengan baik dan akan timbal balik pada tujuan pegawai itu sendiri. Selanjutnya, pada variabel laten kinerja pegawai tenaga kependidikan, indikator Y1.11 (melaksanakan pekerjaan dengan baik dan mencapai target perusahaan) merefleksikan interelasi terbesar dalam menggambarkan kinerja tenaga kependidikan di IPB dengan nilai loading factor sebesar 0,743 . Hal ini sejalan dengan pendapat Zahargier (2011) dalam penelitian nya yang berjudul Factor affecting employees performance in Reasy-Made menyimpulkan bahwa kinerja merupakan hasil kerja secara kualitas dan kuantitas yang dicapai oleh seseorang pegawai dalam melaksanakan tugasnya sesuai dengan tanggung jawab yang diberikan kepadanya. Sehingga semakin tinggi hasil kerja yang dicapai dengan baik oleh pegawai tenaga kependidikan di IPB, maka akan menunjukkan kinerja yang baik pula pada pegawai dan terwujudnya tujuan organisasi maupun tenaga kependidikan di IPB. 


\section{Model Struktural (Inner Model)}

Evalusi inner model dilakukan pengujian melalui dua cara, yaitu mengevaluasi R-square $\left(\mathrm{R}^{2}\right)$ untuk konstruk endogen dan membandingkan $\mathrm{T}$ hitung dengan $\mathrm{T}$ tabel. Telah disebutkan diatas bahwa pada penelitian ini, yang termasuk ke dalam konstruk endogen adalah kinerja pegawai. Hasil analisis diketahui bahwa pada model pengaruh langsung (Model 1) faktor individu, faktor psikologi, dan faktor organnisasi terhadap kinerja pegawai tenaga kependidikan memberikan nilai $\mathrm{R}^{2}$ sebesar 0,489. Nilai $\mathrm{R}^{2}$ dapat diinterpretasikan bahwa variabilitas laten kinerja pegawai tenaga kependidikan dapat dijelaskan oleh variabilitas laten faktor individu, psikologi, dan organisasi sebesar $48,9 \%$, sedangkan $51,1 \%$ dijelaskan oleh variabel lain diluar variabel yang diteliti. Hasil analisis pada model tidak langsung menunjukkan pengaruh faktor individu dan faktor organisasi terhadap faktor psikologi menghasilkan $\mathrm{R}^{2}$ sebesar 0, 240 yang berarti variabilitas laten faktor individu dan faktor organisasi dapat dijelaskan oleh variabilitas laten faktor psikologi sebesar 24,0\%. Model pengaruh faktor individu terhadap faktor organisasi menghasilkan $\mathrm{R}^{2}$ sebesar 0,230 yang berarti variabilitas laten faktor individu dapat dijelaskan oleh variabilitas laten faktor organisasi sebesar $23,0 \%$. Sebaliknya, model pengaruh faktor individu, psikologi, dan organisasi terhadap kinerja pegawai tenaga kependidikan memiliki nilai $\mathrm{R}^{2}$ sebesar 0,477 atau variabilitas laten kinerja pegawai tenaga kependidikan dapat dijelaskan oleh variabilitas laten faktor individu, psikologi dan organisasi sebesar 47,7\%.

Dalam menjawab hipotesis yang diajukan dalam penelitian dilakukan teknik bootsrapping dengan SMARTPLS. Teknik bootsrapping adalah teknik rekalkulasi data sampel secara random untuk memperoleh nilai T-statistik. Melalui metode bootstrapping pada Smart PLS, diperoleh nilai T-statistik sebagai acuan menilai signifikansi statistik model penelitian dengan menguji hipotesis untuk tiap jalur hubungan. Berdasarkan nilai T-statistik yang diperoleh maka dapat diketahui hubungan antar variabel yang di ukur. Selanjutnya, besarnya pengaruh antar variabel dapat dilihat dari kriteria estimasi koefisien jalur masing-masing path yang ada. Gambar analisis data dengan bootstrapping dapat dilihat pada Gambar 5.

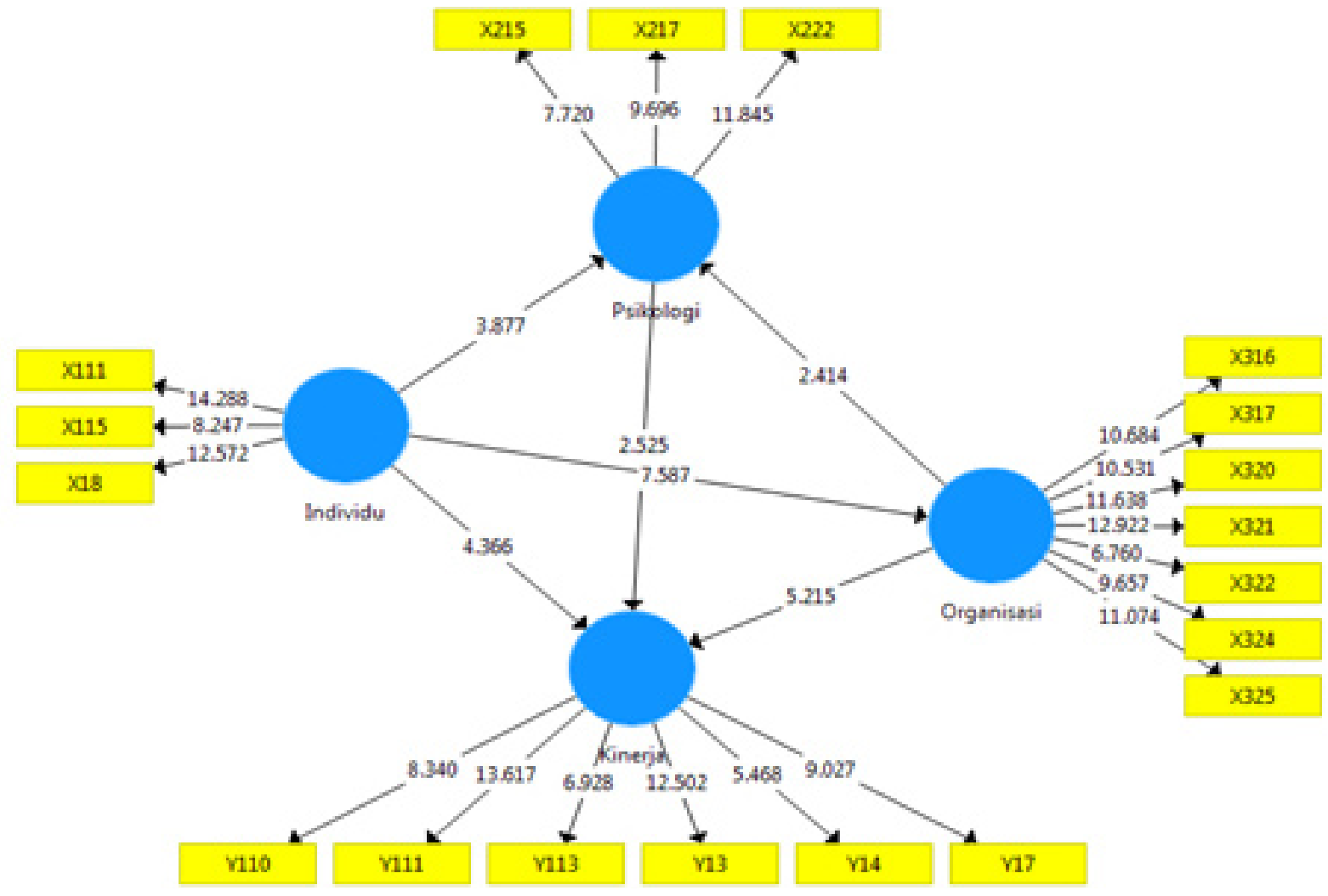

Gambar 5. Hasil metode bootsrapping model pengaruh langsung (direct effect) dan tidak langsung (indirect effect). 
Faktor-faktor yang Berpengaruh Secara Langsung dan Tidak Langsung terhadap Kinerja Tenaga Kependidikan di IPB

Analisis data yang dilakukan dalam penelitian ini adalah menggunakan metode SEM dengan pendekatan PLS dimana perhitungan statistiknya dilakukan dengan software SmartPLS versi 3.0. Analisis data dengan PLS tidak mengasumsikan adanya distribusi tertentu untuk estimasi parameter, sehingga teknik parametrik untuk menguji signifikansi parameter tidak diperlukan (Chin, 1998 dalam Ghazali, 2008). Variabel dalam penelitian ini terdiri dari empat variabel, yaitu faktor individu (X1), faktor psikologi (X2), faktor organisasi (X3) dan kinerja tenaga kependidikan (Y). Setiap variabel laten memiliki masing-masing variabel manifest (indikator) sesuai yang telah dijabarkan sebelumnya pada operasionalisasi variabel.

Hasil penelitian menunjukkan bahwa indikator dari variabel eksogen yaitu faktor individu, faktor psikologi dan faktor organisasi yang tidak berpengaruh atau memiliki pengaruh yang kecil terhadap kinerja pegawai akan dihilangkan. Indikator ini ditandai dengan nilai koefisien yang rendah. Adapun faktorfaktor yang memengaruhi kinerja tenaga kependidikan di IPB dibagi menjadi dua bagian, yaitu faktor-faktor yang berpengaruh secara langsung dan tidak langsung, yang dapat diuraikan sebagai berikut:

\section{Faktor-faktor yang berpengaruh secara langsung terhadap kinerja tenaga kependidikan di IPB}

Dalam model kerangka pemikiran dikembangkan untuk mengetahui faktor-faktor yang secara langsung dan tidak langsung memengaruhi kinerja pegawai, sehingga dapat dirumuskan upaya untuk meningkatkan kinerja tenaga kependidikan di IPB. Faktor-faktor yang berpengaruh secara langsung tersebut terdiri dari tiga faktor, yaitu faktor individu, faktor psikologi dan faktor organisasi.

Pengaruh faktor individu terhadap kinerja tenaga kependidikan

Diketahui bahwa variabel laten faktor individu memiliki faktor positif langsung terhadap kinerja pegawai, dengan koefisien jalur sebesar 0,325. Dengan demikian hipotesis 1 (H1) dapat diterima pada tingkat kepercayaan $95 \%(\alpha=0,05)$ variabel faktor individu juga berpengaruh secara langsung dan signifikan terhadap kinerja tenaga kependidikan di IPB, hal ini ditunjukkan dengan nilai T-statistik yang diberikan sebesar 4,366 (lebih besar dari nilai T-tabel) sehingga Hipotesis 1 pada model ini diterima.

Hasil analisis pada model, terdapat indikator yang dicerminkan oleh variabel faktor individu yaitu peningkatan keterampilan melalui pelatihan. Pelatihan yang diterapkan oleh IPB untuk tenaga kependidikan sangat penting agar bekerja lebih menguasai dan lebih baik terhadap pekerjaan yang dijabat atau akan dijabat kedepan. Dalam organisasi, peningkatan keterampilan melalui pelatihan sering dilakukan sebagai upaya meningkatkan kinerja para tenaga kerja pendidikan yang dianggap belum mampu untuk mengemban pekerjaannya karena faktor perkembangan kebutuhan masyarakat dalarn pendidikan. Secara deskripsi tertentu potensi para tenaga kependidikan mungkin sudah memenuhi syarat administrasi pada pekerjaanya, tetapi secara aktüal para pekerja pendidikan harus mengikuti atau mengimbangi perkembangan pendidikan sesuai dengan tugas yang dijabat atau yang akan dijabatnya. Hal ini yang mendorong pihak instansi pendidikan khusus nya IPB untuk memfasilitasi atau memfasililatori pelatihan dan pengembangan karir para tenaga kerja pendidikan guna mendapatkan hasil kinerja yang baik, efèktif dan efisien. Vazirani (2007) mengemukakan bahwa bila seorang pegawai tidak memiliki kemampuan dan keterampilan yang dibutuhkan bagi pekerja tertentu atau bila pekerja itu tidak berminat pada pekerjaan tersebut maka sulit dipercaya bahwa kinerjanya akan tinggi. Sehingga berdasarkan hasil penelitian dapat dikatakan bahwa keterampilan merupakan cerminan faktor individu yang memang seharusnya memengaruhi kinerja pada model tersebut.

Pengaruh faktor psikologi terhadap kinerja tenaga kependidikan

Diketahui bahwa faktor psikologi berpengaruh secara signifikan terhadap kinerja pegawai dengan nilai T-statistik sebesar 2,295. Variabel laten faktor psikologi yang dicerminkan dengan indikator engagement dan proses pembelajaran berpengaruh secara signifikan terhadap kinerja pegawai dengan koefisien jalur sebesar 0,188 sehingga dapat dikatakan bahwa hipotesis 2 (H2) dapat diterima. Keinginan untuk mempelajari hal-hal baru dan perasaan bahwa pekerjaannya menambah pengetahuan/keterampilan diri merupakan cerminan dari proses pembelajaran dalam penelitian ini. Juhdi (2010) dalamjurnalnyayang berjudulfactorsinfluencing 
internal and external employability of employees, mengemukakan bahwa karyawan dengan diberi dukungan akan mampu melakukan peran yang berbeda dan dipekerjakan dengan cara yang beda, karyawan tersebut dilengkapi dengan pengetahuan yang benar, keterampilan dan kemampuan melalui pengalaman kerja dan program T \& D lainnya. Organisasi harus peka terhadap keinginan pegawai dalammengembangkan diri agar tujuan organisasi dapat tercapai. Menurut Saeed (2013), proses pembelajaran atau belajar didefinisikan sebagai perubahan perilaku yang relatif permanen yang terjadi sebagai hasil dari pengalaman hidup dan dapat dikatakan bahwa perubahan-perubahan perilaku itu menunjukan telah terjadinya proses belajar.

Pengaruh faktor organisasi terhadap kinerja tenaga kependidikan

Hasil penelitian menunjukkan bahwa untuk model, dengan tingkat kepercayaan $95 \%(\alpha=0,05)$ faktor organisasi berpengaruh secara signifikan terhadap kinerja pegawai dengan nilai T-statistik sebesar 4,215 (lebih besar dari T-tabel, yaitu 1,94). Besarnya pengaruh laten eksogen terhadap laten endogen dapat dilihat dari besaran nilai koefisien jalur. Diketahui bahwa variabel laten faktor organisasi memiliki pengaruh positif langsung terhadap kinerja pegawai, dengan koefisien jalur sebesar 0,338. Dengan demikian hipotesis 3 (H3) dapat diterima.

Indikator budaya dan struktur organisasi menjadi indikator yang dominan berpengaruh dalam penelitian ini. Sebuah organisasi yang memiliki budaya yang kuat akan mengakibatkan semua anggotanya akan menganut nilai-nilai yang sama dan menjalankan kegiatan yang relatif bersifat konsisten. Anggota organisasi yang baru akan mengadopsi nilai-nilai dengan cepat, dan seorang pemimpin dapat saja dikoreksi oleh bawahannya jika melanggar norma-norma organisasi. Kuatnya budaya yang ada di sebuah organisasi akan mengakibatkan terjadinya penyatuan tujuan diantara anggota organisasi, sehingga setiap anggota organisasi akan memiliki persamaan tujuan. Penerapan budaya organisasi di IPB merupakan budaya organisasi yang kuat yang membantu kinerja organisasi karena terbukti menciptakan motivasi yang kuat pada setiap pegawai tenaga kependidikan dilihat dari setiap pekerjaan di unit kerja yang dilakukan secara teamwork oleh tenaga kependidikan baik PNS maupun Honorer. Nilai-nilai dan perilaku yang dianut bersama membuat orang merasa nyaman dalam bekerja untuk sebuah instansi ini. Rasa komitmen dan loyalitas akan membuat setiap anggota organisasi untuk berkinerja lebih baik. Jadi, budaya organisasi yang kuat juga akan membantu terciptanya kinerja yang unggul karena memberikan struktur dan kontrol yang dibutuhkan tanpa harus bersandar pada birokrasi formal yang mencekik dan dapat menekan tumbuhnya motivasi dan inovasi.

Hasil penelitian ini menyatakan bahwa struktur organisasi saat ini mendukung pegawai tenaga kependidikan dalam bekerja, memberikan ide pada pimpinan, serta sistem pelaporan pekerjaan yang dinilai sudah baik. Sehubungan dengan itu, struktur organisasi di Institut Pertanian Bogor dikatakan struktur yang tinggi bila dilihat dari model pengaruh langsung dan model pengaruh tidak langsung. Struktur organisasi yang tinggi sejalan dengan dengan desain pekerjaan, hal ini dikarenakan bahwa struktur organisasi yang mempunyai wewenang untuk mengambil keputusan dalam menentukan pekerjaan yang ditetapkan organisasi telah sesuai dengan situasi kerja yang dijalani seharihari oleh pegawai tenaga kependidikan di IPB. Atasan yang selalu mengingatkan untuk bekerja sesuai dengan tupoksi pekerjaan yang telah ditetapkan oleh organisasi. Hasil penelitian ini sejalan dengan penelitian Marlikan (2011), Luhgiatno (2006), dan Budiasih (2012) yang menyatakan bahwa kepemimpinan, desain pekerjaan dan pengawasan berpengaruh terhadap kinerja karyawan.

\section{Faktor-faktor yang berpengaruh tidak langsung terhadap kinerja tenaga kependidikan di IPB}

Pencapain kinerja suatu organisasi sangat ditentukan oleh sumber daya manusia yang berada di dalamnya sesuai dengan tugas pokok dan peranan fungsi yang harus dilaksanakan dengan tingkat kemampuan khusus yang diperlukan dari pegawai. Kinerja merupakan suatu konstruk multidemensional yang mencakup banyak faktor yang memengaruhinya. Faktor-faktor yang memengaruhi kinerja pegawai sangat beragam, hal ini perlu diketahui agar instansi mengetahui arah pengembangan sumber daya manuasianya sehingga lebih tepat sasaran sesuai kebutuhan pegawai. Dalam model ini juga terdapat analisis pengaruh tidak langsung yaitu faktor individu terhadap kinerja pegawai melalui faktor psikologi dan faktor organisasi terhadap kinerja melalui faktor psikologi. Dari dua analisis pengaruh tidak langsung ini, dapat diuraikan dalam penjelasan berikut: 
Pengaruh faktor individu terhadap faktor psikologi

Diketahui bahwa pengaruh faktor individu pada faktor psikologi memberikan nilai koefisien positif sebesar 0,335 . Hal ini dapat diartikan bahwa ketika faktor individu dioptimalkan maka akan meningkatkan faktor psikologi sebesar 33,5\%. Sehingga dapat dikatakan bahwa faktor individu berpengaruh terhadap kinerja pegawai melalui faktor psikologi atau dengan kata lain penempatan pegawai tenaga kependidikan sesuai kemampuan dari tingkat pendidikan, keterampilan dari hasil pelatihan, demografi berdasarkan jenis kelamin serta kebijakan promosi tanpa melihat perbedaan gender dapat meningkatkan keterikatan kerja/ engagement dan motivasi pegawai yang pada akhirnya dapat meningkatkan kinerja pegawai.

\section{Pengaruh faktor organisasi terhadap faktor psikologi}

Hasil dari pengaruh factor organisasi terhadap factor psikologi menyatakan bahwa faktor organisasi berpengaruh terhadap faktor psikologi sehingga hipotesis 5 dapat diterima. Besarnya pengaruh antar variable laten faktor organisasi terhadap faktor psikologi memberikan nilai koefisien jalur sebesar 0,232. Hal ini dapat diartikan bahwa ketika faktor individu dioptimalkan maka akan meningkatkan faktor organisasi sebesar 23,2\%. Pada indikator desain pekerjaan peran pemimpin/atasan dalam pembagian tugas sesuai tupoksinya sangat diperlukan. Desain pekerjaan merupakan perancangan tugas pegawai yang ditujukan untuk efisiensi dan efektivitas kerja. Perancangan tersebut dimaksudkan untuk menjalankan roda organisasi sesuai dengan kebutuhan organisasi dan tuntutan masyarakat. Hal ini sejalan dengan penelitian Mariono, (2012) yang menyatakan bahwa desain pekerjaan akan berpengaruh terhadap kepuasan kerja yang merupakan variabel psikologi dalam penelitian ini dan kemudian berpengaruh terhadap kinerja pegawai.

Pengaruh faktor individu terhadap faktor organisasi

Faktor individu pada model pengaruh tidak langsung berpengaruh secara signifikan terhadap faktor organisasi. Hal ini dapat dilihat dari nilai T-statistik pengaruh faktor individu terhadap faktor organisasi sebesar 7,587 (diatas nilai T-tabel) sehingga Hipotesis 6 diterima dengan nilai koefisien jalur faktor individu terhadap faktor organisasi sebesar 0,479. Hal ini menunjukkan bahwa peningkatan faktor individu yaitu penempatan sesuai kemampuan pendidikan, keterampilan dari pelatihan dan jenis kelamin dapat memengaruhi pola kepemimpinan, pengawasan dan desain pekerjaan pada pegawai tenaga kependidikan di IPB sebesar $47,9 \%$. Hal ini sesuai dengan penelitian Zahergier (2011) yang menyatakan terdapat pengaruh yang signifikan antara faktor yang terkait individu dengan faktor yang terkait organisasi.

Faktor dominan yang memengaruhi kinerja tenaga kependidikan

Secara keseluruhan faktor dominan yang memengaruhi kinerja tenaga kependidikan di IPB tidak hanya dilihat dari pengaruh secara langsung tapi juga dari faktor yang didukung oleh faktor lain secara tidak langsung, sehingga dapat dikatakan bahwa latar belakang, keterampilan, demografi, engagement, proses pembelajaran, budaya dan struktur organisasi, dari ketiga faktor individu, psikologi, dan organisasi tersebut adalah faktor yang dominan berpengaruh terhadap kinerja tenaga kependidikan di IPB. Faktor dominan yang berpengaruh secara langsung terhadap kinerja pegawai adalah latar belakang, demografi engagement, proses pembelajaran, budaya dan struktur organisasi. Sedangkan faktor keterampilan, proses pembelajaran, dan desain pekerjaan merupakan faktor dominan yang berpengaruh secara tidak langsung terhadap kinerja tenaga kependidikan di IPB. Dapat disimpulkan bahwa faktor-faktor yang memengaruhi kinerja tenaga kependidikan baik secara langsung maupun tidak langsung adalah faktor organisasi.

\section{Implikasi Manajerial}

Hasil analisis yang telah dilakukan mengenai faktorfaktor yang memengaruhi kinerja tenaga kependidikan di IPB, faktor utama yang memengaruhi kinerja tenaga kependidikan pada model pengaruh langsung diantaranya adalah faktor individu, faktor psikologi, dan faktor organisasi. Latar belakang merupakan hasil dominan yang mencerminkan faktor individu yang harus menjadi perhatian utama organisasi untuk ditingkatkan sehingga secara simultan dapat meningkatkan kinerja tenaga kependidikan di IPB. Latar belakang dapat ditingkatkan melalui pendidikan, pengalaman kerja, serta dukungan dari keluarga. Variabel laten faktor psikologi yang dicerminkan dengan indikator engagement menjadi faktor dominan yang berpengaruh terhadap kinerja tenaga kependidikan di IPB. Instansi harus mengetahui bahwa tenaga kependidikan yang memiliki tingkat engagement tinggi 
akan memiliki keterikatan emosi yang tinggi terhadap organisasi. Tenaga kependidikan yang terikat akan termotivasi untuk meningkatkan produktivitasnya, mau menerima tantangan dan merasa pekerjaannya memberi makna bagi dirinya. Budaya organisasi menjadi indikator yang dominan berpengaruh pada model pengaruh langsung dalam faktor organisasi pada penelitian ini. Penerapan budaya organisasi di IPB perlu ditingkatkan dan diterapkan dalam unit kerja, karena budaya organisasi yang kuat yang membantu kinerja organisasi akanterbukti menciptakan motivasi yang kuat pada setiap tenaga kependidikan dilihat dari setiap pekerjaan di unit kerja yang dilakukan secara teamwork oleh tenaga kependidikan baik PNS maupun Honorer.

Hasil penelitian pada model pengaruh tidak langsung, pengembangan faktor individu dan faktor organisasi lebih ditujukan untuk meningkatkan faktor psikologi untuk dapat meningkatkan kinerja tenaga kependidikan di IPB. Faktor psikologi yang dicerminkan oleh proses pembelajaran dan desain pekerjaan menjadi faktor yang harus diperhatikan karena faktor ini merupakan faktor dominan yang berpengaruh terhadap kinerja tenaga kependidikan di IPB. Untuk meningkatkan proses pembelajaran dan desain pekerjaan perlu memperhatikan faktor lain yang berasal dari faktor faktor individu dan organisasi, yaitu pihak instansi seharusnya memperhatikan sumber daya manusia khususnya pada tenaga kependidikan dengan memberikan kesempatan untuk mengikuti pendidikan/ pelatihan yang mendukung pekerjaan.

\section{KESIMPULAN DAN SARAN}

\section{Kesimpulan}

Faktor-faktor yang memengaruhi kinerja tenaga kependidikan di IPB berasal dari faktor individu (latar belakang keluarga mendukung karir dan pekerjaan di organisasi), faktor psikologi (pekerjaan menambah keterampilan/pengetahuan) dan faktor organisasi (sumber daya, struktur kerja, dan budaya organisasi). Dari model pengaruh langsung dan tidak langsung, latar belakang keluarga mendukung karir dan pekerjaan di organisasi menjadi indikator yang sama dalam mencerminkan faktor individu.
Faktor psikologi yang dicerminkan oleh tiga indikator yaitu proses pembelajaran, motivasi, dan engagement berpengaruh secara langsung terhadap kinerja tenaga kependidikan di IPB. Sedangkan faktor psikologi yang berpengaruh secara langsung dan tidak langsung terhadap kinerja tenaga kependidikan di IPB yaitu indikator proses pembelajaran dan engagement. Variabel laten faktor organisasi dicerminkan oleh tujuh indikator yang sama yang menggambarkan tiga dimensi faktor yang memengaruhi kinerja yaitu sumber daya, struktur kerja, dan budaya organisasi.

Secara keseluruhan faktor dominan yang memengaruhi kinerja tenaga kependidikan di IPB secara langsung terhadap kinerja pegawai adalah latar belakang, demografi engagement, proses pembelajaran, budaya dan struktur organisasi. Sedangkan faktor keterampilan, proses pembelajaran, dan desain pekerjaan merupakan faktor dominan yang berpengaruh secara tidak langsung terhadap kinerja tenaga kependidikan di IPB.

\section{Saran}

Institusi perlu memperhatikan pengembangan diri dan keahlian tenaga kependidikannya, khususnya dalam meningkatkan kinerja. Salah satunya adalah dengan memberikan proses pembelajaran yaitu pelatihanpelatihan yang dapat mendukung pelaksanaan pekerjaan tenaga kependidikan, seperti pelatihan mengoperasikan komputer, inventarisasi ruangan dan alat-alat kantor, persuratan dan arsip-arsip. Selanjutnya, institusi perlu lebih memberikan proses pembelajaran dan pengakuan kerja terhadap tenaga kependidikannya agar kinerja tenaga kependidikan dapat ditingkatkan menjadi lebih baik lagi.

Perlu diadakan penelitian lebih lanjut mengenai karakteristik responden dengan melihat hubungannya dengan faktor-faktor yang memengaruhi kinerja, yaitu menggunakan analisis crosstab (tabulasi silang) dengan metode chi-square.

\section{DAFTAR PUSTAKA}

[Anonim]. Ranking of Universities of Indonesia.http:// www.webometrrics.info.[9 Januari 2016].

[Anonim]. Pemeringkatan Perguruan Tinggi Berdasarkan Kemenristek. http://www.ristek. go.id.[25 Desember 2015]. 
Budiasih Y. 2012. Struktur organisasi, desain kerja, budaya organisasi dan pengaruhnya terhadap produktivitas karyawan. Jurnal Liquidity 1(2): $100-105$.

Boriban O. 2014. Employee motivation factors that affect job performance of Suan Sunandha Rajabhat University Employee. International Journal of Social, Behavioral, Educational, Economic, Business and Industrial Engineering $8(9): 1-4$.

Ghazali I. 2008. Structural Equation Modelling (SEM) metode alternative dengan Partial Least Square. Semarang: Badan penerbit Universitas Diponegoro Semarang.

Gibson Jl. 2000. Organisasi, Perilaku, Struktur, Proses. Jakarta: Penerbit Erlangga

Hadi S. 2007. Pengaruh tindakan supervisi terhadap kepuasan kerja akuntan pemula. Jurnal Akuntansi dan Auditing Indonesia 11(2): 187-198.

Hameed A. 2009. Impact of office design on employees productivity: a case study of banking. Journal Business of Pakistan (3): 229-236.

Hewitt A. 2011. What is employee engagement. Journal Best Employers Study 5(1): 59-76.

Irawan A, Maarif MS, Affandi MJ. 2015. Faktor-faktor yang memengaruhi kinerja pegawai negeri sipil di Direktorat Jenderal Pendidikan Tinggi. Jurnal Aplikasi Bisnis dan Manajemen 1(1): 55-64.

Juhdi N, Pa'Wan F, Othman NA, Moksin H. 2010. Factors influencing internal and external employabilityof employees. Journal Faculty of Business Administration 2010: BEJ-11

Kahn WA. 1990. Psychological conditions of personal engagement and disengagement at work. Academy of Management Journal 33(4):694702.

Luhgiatno. 2006. Pengaruh motivasi dan kemampuan terhadap kinerja. Jurnal pada Fokus Ekonomi 1(1):1-12.
Mariono A. 2012. Analisis pengaruh desain pekerjaan dan stress kerja terhadap kepuasan kerja dan dampaknya terhadap kinerja karyawan di Departemen Krisbow PT. Kawan Lama Sejahtera. (tesis). Jakarta: Departemen School of Businesss Management Bina Nusantara University.

Marlikan M. 2011. Pengaruh pembelajaran organisasi dan motivasi kerja terhaddap kinerja karyawan koperasi syariah. Jurnal Manajemen Bisnis 1(1): 57-64.

Munawaroh A, Riantoputra CDS, Marpaung S. 2013. Factors influencing individual performance in an indonesian goverment office. Journal Universitas Indonesia 7(2):51-60.

Osibiya B. 2014. The effect of employees motivation on organizational performance. Journal of Public Administration and Policy Research 7(4):62-75.

Perrin T. 2003. Working Today: Understanding What Drives Employee Engagement. India: Indian Journal of Fundamental and Applied Life Sciences.

Saeed R. 2013. Factors affecting the performance of employees at work place in the banking sector of Pakistan. Journal Departement Of Management Sciences 17(9): 1200-1208.

Ton Z. 2013. Managing the impact of employee turnover on performance: the role of process conformance. Journal Organization Science 19(1): 56-68.

Thao L. 2010. Factors affecting employee performance evidence from petrovietnam engineering consultancy j.j.c. American Journal of Industrial and Business Management 3:229-236.

Vazirani. 2007. Employee engagement working paper series. Journal SIES College of Management Studies 5(7): 3-9.

Zahargier MS, Balasundaram N. 2011. Factor affecting employees performance in Reasy-Made Garments (RMGs) sector in Chittagong. Journal of Economic Sciences LXIII(1): 9-15. 